\title{
AMERICAN TRAVELERS IN MALLORCA IN THE TWENTIETH CENTURY: THE HARD WORK OF THE NOTHING-TO-DO'S
}

\author{
Eduard Moyà \\ Universitat de les Illes Balears (UIB), Mallorca
}

Abstract

British travelers in the nineteenth century created the construct of the Balearic Islands as a remote and isolated paradise. In the twentieth century, they reified their fantasies about the islands as places devoted to artistic fulfilment, and sensual joy at a very cheap cost. Was this also true for the American traveler? This article examines to what extent American travelers followed the discourse of leisure and pleasure established by British travelers on the island of Mallorca. I will therefore analyze what are the recurring and diverging points. The travel writers examined range from artists, bohemians and writers such as William E. Cook, Gertrude Stein, and Jesse Metcalf, to Frederick Chamberlin and Elliot Paul. British travel accounts will also be reviewed in order to analyze the not-so-flattering representations of American travelers. Ultimately, the study of these representations will help us to see whether these differences have helped create a particular view of the islands for the present day American travel market coming to Mallorca and in current popular travel literature.

Keywords: Mallorca, Travel, American Literature, Tourism, Expatriates.

\section{VIAJEROS AMERICANOS EN LA MALLORCA DEL SIGLO XX. EL DURO TRABAJO DE LOS HOLGAZANES}

\section{RESUMEN}

Los viajeros británicos en el siglo xIX construyeron la idea de las Illes Balears como un paraíso remoto y aislado. En el siglo xx estos revivieron sus fantasías en las islas dedicados a la realización artística y a la alegría sensual a un precio muy barato. ¿Fue así también para el viajero americano? Este artículo examina hasta qué punto los viajeros estadounidenses siguen el discurso de ocio y placer establecido por los viajeros británicos en Mallorca. Para ello, analizo cuáles son los puntos recurrentes y divergentes entre unos y otros. Los escritores de viajes norteamericanos estudiados cuentan con artistas, bohemios y escritores como William E. Cook, Gertrude Stein, Jesse Metcalf, Frederick Chamberlin o Elliot Paul. También examino la representación no tan halagadora que de los viajeros estadounidenses hacen algunos relatos de viajes británicos. En última instancia, el estudio de estas representaciones nos ayuda a comprender la construcción de una visión particular en la actual industria turística y literatura popular norteamericana en las islas.

Palabras Clave: Mallorca, viaje, literatura norteamericana, turismo, expatriados.

DOI: http://doi.org/10.25145/j.refiull.2019.38.011

Revista de Filología, 38; enero 2019, pp. 169-183; ISSN: e-2530-8548 
It is not difficult to associate Mallorca ${ }^{1}$ today with a summer tabloid front-cover showing American celebrities such as Tom Hanks or Bruce Springsteen strolling along a picturesque Mediterranean port or sipping wine on a sunny terrace ${ }^{2}$. According to Emma Straub, author of the best-selling novel The Vacationers (2014), set in Mallorca, the island "represents a kind of European ease that doesn't exist in the continental U.S. -think two-hour lunches with multiple bottles of wine». In Straub's opinion, "this Spanish island, long a favorite for Europeans, is the perfect destination for island-bound Americans» (2005). To put it simply, Mallorca is "the ever popular star of the Mediterranean» (Lonely Planet 2017).

The study Journeys in the Sun (Moyà 2016) inspects how British travel writing in the late nineteenth and early twentieth centuries created the construct of the Balearic Islands as a remote and isolated paradise. British travelers and their travelogues gave life to their fantasies on the islands, devoting their time to artistic fulfilment and sensual joy at a very cheap cost. The island of Mallorca, overlooked as it had been by the eighteenth century's European Grand Tour, became, at the turn of the twentieth century, a promising destination for British travelers, artists, and bohemians. These visitors would later be classified by the locals as extranjeros (Waxman 1933: 44) or just inglés (Flitch 1911: 49). That is, international tourists who, according to the locals, seemed to have nothing to do but spend hours writing, painting and savoring life in the sun. Ironically, through their travel writing and creativity, these visitors helped develop an ideal haven not only for the artist and poet, but also for the tourist and tourism industry. At this point, studies in imagology, the study of cultural stereotypes as represented in literature (Beller and Leerssen 2007), are useful to examine whether this pattern of representation also exists in the case of the American travelers to Mallorca and their travelogues in the twentieth century.

This article is therefore a short biographical account of American visitors to Mallorca and a first attempt at analyzing their depiction of the island. This study intends to briefly review to what extent American travelers follow the discourse of leisure and pleasure established by British travelers on the largest of the Balearic Islands. These visitors include artists, bohemians, travelers and writers such as Gertrude Stein, Jesse Metcalf, Frederick Chamberlin, Percy Waxman, Robert Creeley and Paul Theroux, among others. This article also considers British travel accounts and their not-so-flattering representation of American travelers (as in the case of Gordon West's, and Francis Caron's travelogues). Ultimately, the study of these representations helps us to see whether these differences have contributed to creating a particular view of the islands in current American popular literature.

1 This article uses both local and English written forms for the island's name, i.e. «Mallorca» and «Majorca». The same principle applies to towns: «Deià» and «Deyá».

2 Actors Tom Hanks and Halle Berry lived on the island during the shooting of Cloud Atlas. The American songwriter is an enthusiast of the Balearic Islands during the summer. See Ultima Hora (2013). 


\section{GERTRUDE STEIN, LITERARY JOURNALS, AND A SUNNY ISLAND FAR FROM THE WAR}

A 1925 article entitled «Old Majorca Has Many Charms» from The New York Times described Mallorca as «the haunt of literary folk and artists. Off the beaten track of tourist travel, [it] has attractions for the lover of solitude, while its semi-tropical climate and rare scenery lure the artist» (Jenkins 1925: 16). How did a poorly-connected island such as Mallorca at the beginning of the twentieth century acquire its moment in the sun among «literary folk and artists»? The bohemian and artistic allure of Mallorca is the fruit of a dense net of social and artistic connections. Gertrude Stein was a seminal figure in the web of connections that shaped perceptions of Mallorca. The American expatriate, poet and art collector decided to spend the winter of 1915 in Mallorca «to forget the war a little» (Stein 1933: 198). Stein, together with her partner Alice B. Toklas, arrived on the island at the recommendation of American painter William E. Cook. He, in turn, was surely following the suggestion of Art-Nouveau artist Santiago Rusiñol, a habitué of the bohemian salons in Paris ${ }^{3}$.

In the chapter entitled «The War» in The Autobiography of Alice B. Toklas (1933), Stein mentions that "[a] great many americans [sic] seem to like» the island (200) and that «a certain kind of landscape induces [the writing of] plays, and the country around Terreno did» (202). It was indeed, in the neighborhood of El Terreno (Palma), that she wrote the texts of Geography and Plays (1922), an example of Cubist poems and plays in which the presence of the island, whether intentionally or not, is ever present ${ }^{4}$. One example is the play "Do Let Us Go Away", in which a myriad of allegedly random conversations happen in a house by the bay of Palma:

The weather in June is like the weather in September. The end of May is cooler.

The bathman is disgusted that the Mallorcans don't bathe in September. The water is warm in September. It is warmer in July and August.

(The War.) Are there German submarines 5 in Spanish waters.

${ }^{3}$ Rusiñol's connection with the island comes from meeting Llorenç Cerdà, a Mallorcan artist, at the Barcelona Universal Exposition (1888). Cerdà invited him to go to Majorca and paint (Fábregas 1957: 43). Rusiñol rented a house in the suburb of El Terreno (Palma), where he painted and wrote La isla de la calma in 1912 (translated into English as The Tranquil Isle, 1930). In this travelogue, the artist praises the picturesqueness and ease of Mallorcan life. Rusiñol frequented bohemian meetings in Paris, where he most probably met Cook. Years later, Cook and Stein took up residence in El Terreno, only a few streets away from the house where Rusiñol had lived and worked. Another renowned American artist, John Singer Sargent, founder of American Impressionism, sought inspiration in Mallorca, where he painted during his visit in 1908. Sargent also frequented the Parisian artistic bohemia.

${ }^{4}$ See Jessop (2016) to examine the relationship between place and creative language in the modernist literary movement of Anglo-Saxon writers on the island.

5 German submarines remain a recurring motif of the Great War in the minds of the Mallorcan locals. American journalist P.B. Harnden recalls ten years after the war that «[t]he World 
(Signor Dato.) There are no german [sic] submarines in Spanish waters.

(Marquis of Ibyza.) I hate the English (223).

Elements like the sea, the quaint landscapes (that «induce plays»), the pleasant weather and the ever pervading idleness, create, in the the eyes of the American bohemians, a perfect combination for a captivating destination. Once they had enough rest, Stein, Toklas and Cook urged for some action far from the «tranquil isle»: «When it was all over none of us wanted to stay any longer, we all wanted to go home [Paris]. It was at this time that Cook and Gertrude Stein spent all their time talking about automobiles» (Stein 1933: 186). Later in the article, I will examine the American interest in automobiles on the island and their connection with the distaste for wasted time.

It was precisely to escape from interference that American modernist poet Laura Riding (on Stein's recommendation) ${ }^{6}$ set foot in Mallorca, together with English poet Robert Graves, who in 1929 decided «never to make England [his] home again» (Graves 1957: 279). Graves explained that on Mallorca, he and Laura Riding found everything they could wish for as a background to their artistic work: «sun, sea, mountains, shady trees, no politics, and a few civilized luxuries» (1965: 13). Again, an inviting milieu where the "nothing-to-do" artists could fulfill their creative fantasies. Riding and Graves established the Seizin Press in Mallorca; Riding served as managing partner until 1938. Riding and Graves also edited Epilogue, a journal in which they explored new principles of textual analysis that were to influence the development of the New Criticism. In Epilogue, contributors such as John Aldridge, Thomas Matthews, John Cullen, James Reeves, Honor Wyatt, Len Lye, Ward Hutchinson, Norman Cameron, Kenneth Allott, Alan Hodge, Sally Graves and Jacob Bronowski participated with their writings, contributing to exploring and developing ideas about literary criticism and the nature of poetry. Many of them spent short stays in Mallorca with Riding and Graves. On the island (particularly in the town of Deià), these authors found the perfect, peaceful place in which to obtain inspiration and come in contact with the natural rhythms of rural life. Accordingly, Riding said: "When you're in Deyá you're in Deyá», giving full credit to the role of consciousness of the place in the creative and living process (Riding 1935). In a retreat such as Canelluñ, Graves's and Riding's country house in Deià, writers could fulfill themselves entirely in the orchard as well as with their work:

In the early part of the month we had the beginning of artichokes, and the Madona explained how to get the best tastes from them; this seems to have mostly to do with cutting them in sharp ways. The rest of the month I forgot about artichokes and finally finished off the first EPILOGUE volume, which has now gone to a publisher, who is considering (Riding 1935: n.p.).

\footnotetext{
War touched Majorca only slightly, although the natives complained even there of high prices. [...] The German submarines profited by the prices and came for supplies» (1924: 431).

6 See Robert Graves's Goodbye to All That (1957) [1929].
} 
The combination of a warm and inexpensive island, together with the attraction of Stein's influence, made Mallorca a refuge for many young American poets and writers desirous of developing their projects at a cheap cost. Whitt Burnet and Martha Foley, young American journalists and editors, published four issues of Story in Mallorca during the 1930s. Story was a literary magazine devoted to short narratives that featured Stein, Faulkner, Bukowski and Salinger as some of its collaborators. Furthermore, Jean Rivers and Sydney Salt published the literary journal Caravel from 1934 to 1936 on Mallorca. Caravel provided a convenient platform for poets and writers such as William Carlos Williams, Blaise Cendrars, Dylan Thomas, Edith Sitwell, Ruthven Todd, Charles Henri Ford and Djuna Barnes to share their work and establish creative dialogues between expatriates living in Europe. In Issue 2 of Caravel, James Laughlin IV's article "A Natural History» describes his bold decision to publish in a Mallorcan journal (Caravel, of course) after a long creative block during his time in bohemian Paris (1934: 37). What his story does not explain, however, is that around the same time he had met Ezra Pound, who suggested that the young Laughlin give up poetry and take up something useful instead. The publishing of "A Natural History» in Caravel was probably Laughlin's first printed narrative after his meeting with Pound. Providentially, Caravel can claim to have witnessed the birth of one of the most successful publishers of modernist American poetry'.

The affordability of Mallorcan publishing stretched as far as 1952, when American beatnik poet Robert Creeley established himself on the island and founded the Black Mountain Review (1954-57), which he edited. This literary magazine became a spearhead creative platform for American ports in the 1950s. Kevin Power, the editor of Creeley's poems puts it bluntly: «He came to Majorca for two essential reasons: firstly, because it was cheaper to live; and secondly, because it provided the possibility of cheap printing» (Creeley 2002: 158).

Mallorca's allure, however, did not only attract literary journal editors and poets, but also vacationers and sun-lovers. News of the cheap cost of Mallorcan living, paired with Stein's favorable recommendations, spread like wildfire amongst the Paris expats and bohemians and, particularly during the 1920s and 30s, when "[a]ll sorts of holidaymakers came to [Mallorca]: painters, professors of literature, dipsomaniacs, pianists, perverts, priests, geologists, Buddhists, run-away couples, vegetarians, Seventh Day Adventists, but especially painters» (Graves 1965: 13). This mixed bag of visitors to Mallorca between World War I and World War II found a vibrant island seesawing between an inspiring rural landscape and a fast-growing sun-and-fun location.

7 In 1936, Laughlin founded New Directions in Prose \& Poetry, a new press which worked as an anthology of poetry and writings by authors such as William Carlos Williams, E.E. Cummings and Henry Miller. Laughlin was awarded the Robert Frost Medal in 1990 and the National Book Foundation Medal for Distinguished Contribution to American Letters in 1992. 


\section{TRAVELING SOUTH BETWEEN THE WARS: THE ROARING SOLACE BEFORE THE DELUGE}

American travelers in the 1920s and 30s traveled to Mallorca for disparate reasons. Some wanted to ally themselves with the creative scenario that connected the visitor with the timeless and undisturbed pre-war era. For others, the horrific life of the World War I trenches, followed by the prosperous post-World War I American economy, gave rise to a new type of well-to-do traveler, interested in a more active type of vacationing focused on sensual pleasures ${ }^{8}$. Tourism also «brought cultural capital and social prestige. Many believed that getting away from day-to-day was healthy, even vital to a long happy life» (Zuelow 2016: 135). As a consequence, quiet resorts such as El Terreno -where Stein, Toklas and other artists had lived and created-metamorphosed, not without tensions, into lively social hubs for the American and international community?

For the first type of visitor, the "creative» travelers, the island was still a garden of inspiration and seclusion. Duryea described life in Mallorca as «a serene thing» (1927: 172). She suggested using a carriage - not an automobile- when visiting the island: "[a]s a mule is of a contemplative disposition, he [the traveler] can be left by the roadside while luncheon is eaten» (77). Later, Duryea provided some hints on enjoying the island's hideaway: "on some sequestered beach, one can bathe minus bathing-suit, for there is no-one to be shocked but the saints and the gulls» (77). Solitude and seclusion were the main attractions for the reflective visitor. Rural peripheries such as Deià, Sóller or Pollença established themselves as quiet options for the more artistic traveler (Moyà 2015). Percy Waxman, American journalist and author of What Price Mallorca (1933), remarked that in Port de Pollença one could find «many artists, musicians, and novelists, a poet or two, a New York playwright, a Hollywood scenario writer and one industrious Englishman who turned out 40.000 words of fiction every week" (136). According to Waxman, the north of the island «has always possessed a magnetic attraction for writers, painters, sculptors, and musicians» (136). The writer expressed, not without surprise, that these artists and poets «flock from all over the world» (136). This growing attraction and easy accessibility to Mallorca led to the emergence of a more dynamic and less contemplative sort of traveler: the cruiser.

This more active cruise traveler arrived on the island in significantly increasing number and at a fast rate during the $1920 \mathrm{~s}$ and $1930 \mathrm{~s}^{10}$, wondering «[w]hy the Balearic Islands should be so little known to the modern tourist» (Harnden 1924: 425). Cruise liners from the most important American ports were established to

${ }^{8}$ See Hynes's The Auden Generation (1976) and Fussell's Abroad (1980).

9 Strong networking proved particularly effective among American tourists. These connections eventually created the "American Club» and La Residencia Americana in the neighborhood.

${ }^{10}$ See Buswell (2011) for itineraries, and economic growth that resulted thanks to the tourist industry. For an accurate historical and economic context of the islands at the time see Cirer-Costa (2014). 
create links with this «garden spot in the Mediterranean» (Waxman 1933: xiii; The New York Times 1932: 8). The popularity of Mallorca as a destination changed local town rhythms and made Palma's port a boisterous mêlée of taxis, automobiles and tour guides eager to attract the swarms of new visitors. Local journalists reported that "primeramente comienza el desfile de coches abarrotados de viajeros, en larga e interminable hilera como una procesión verdaderamente pintoresca» (Linares 1928: 34) ${ }^{11}$. In Mallorca: The Diary of a Painter (1939), artist Francis Caron described the crowds of porters trying to catch the tourists' attention at the port of Palma: «The shouts begin when the ship is still more than a hundred yards away from the quay, and they increase to an unbelievable din by the time she is tied up" (3). The 'tranquil isle' had its days numbered.

Jesse Metcalf, American retired businessman and author of Wandering Among Forgotten Islands (1926), is an example of the traveler who moved easily from the quiet-island scenery to fast paced tourism. Metcalf visited the island on a cruise expedition using a four-mast schooner. The account of his short journey through the island deploys the fully-spiced discourse of discovery narratives: Metcalf explores wild grottos (81), ventures inland to hunt birds for his collection (94) and tours the island on a cloudless morning that "held promise of great heat» (98). Metcalf's way of moving around the island, however, differed significantly from that of earlier travelers; he used an automobile: «At an early hour we embarked in two small cars of excellent make but of pre-War, almost pre-historic origin» (72). The car tour rapidly emerged as the sign of the new type of American traveler.

The American tourist and the roaring car, «that machine of evil» (Duryea 1927: 79), proved commonplace in many American travelogues about Mallorca at the time. While the British visitor, in a fit of staged authenticity, preferred the quaint horse carriage to tour about the island (Boyd 1911, Harrison 1927), the American counterpart oftentimes chose the motor-car to move quickly, in order to make the most of his stay. The American vice-consul on the island during the 1930s explained that "[ $\mathrm{t}]$ he American is so wound up that if he does not work he will go mad. The idle Englishman can keep out of Bedlam by sport, but the American has to work to escape that same confinement» (Chamberlin 1927: 32). The artistic work of the aforementioned "nothing-to-do" artist turned into into a frantic collection of tourist markers ${ }^{12}$. This conscientious way of traveling represents the epitome of the new travel ethos. The symbolic way of working translates into «seeing» the island in the least amount of time while covering as much of the island as possible. In Jogging Round Mallorca (1929), British travel writer Gordon West narrates a sudden encounter with this new, noisy type of traveler: «We had reached a point out of Deyá when there was a noise of motor-cars behind us [...] travelling at forty miles per hour» (154).

11 «First it starts with a long and interminable parade of cars packed with travelers, creating a truly picturesque procession" (My translation).

12 Dean MacCannell's The Tourist (1976) and John Urry's Consuming Places (1995) prove especially clarifying when explaining the relationship between the tourism industry as a modern product of capitalist societies and their commodification of the tourist experience. 
Silence, and the absence of speed on the «forgotten island» had hitherto worked as an attraction for many British visitors to Mallorca. These elements, however, do not figure in the desires of the new type of traveler: «It was full of men and women: the men goggled, huddled together, holding on to their hats, and shouting into each others ears to make themselves heard [...]. The car roared past. Another swung round the corner, and another» (154). West shares his astonishment and bewilderment with the reader: «You have guessed correctly: the cars carried rich American tourists. They are 'doing' Mallorca» (155). This animosity towards American tourists positions the self-appointed «real» traveler with the «authentic» local. West, seeing the sweating owner of a fonda, inquired if the heat was the cause: «The heat señor? No, it is not the heat, it is the Americanos. Oh! Los Americanos! They come like a swarm of flies to be fed, down on me they come -whoof!- And I have to search all the town for food enough to feed them» (158). Nina Larrey Duryea shared the same opinion of the new travelers and their rowdy ways. According to her, "[t]hose machines of noise and smell which whisk the visitor through beloved scenes» (79) materialize as a cursed sign of the new times and the new traveler. Therefore, the "real» traveler should avoid using a car around the quaint island: «Motor cars should be avoided [...]. They are expensive and whisk the traveler through paradise as though the devil himself was concealed in their cloud of dust» (77). The loud and loathsome car epitomizes the new «obnoxious type of American tourist» (Metcalf 1927: 110) that so many self-appointed travelers looked down on.

As I mentioned before, Mallorca at this time was witnessing a struggle between those who sought an idle paradise and those ready to consecrate a sanctuary devoted to fun for the new traveler. This latter phenomenon was responsible, not without objection, for the first signs of mass tourism on the island. Although Waxman indicated in 1933 that the "demon Progress» (128) had not made Mallorca a victim of the "Machine Age», R.A. Cram, the prolific and influential American architect, already warned the future visitor against the intentions of entrepreneurs on Mallorca. Cram suggested enjoying the place before tourism «covers the whole island, with palatial hotels, garages, movie houses, casinos, roller coasters, and all the other products of civilization" (Duryea 1927: xiii). The center of the the devil's realm is -again-El Terreno neighborhood ${ }^{13}$. Waxman notes that "[t] he best houses of Palma are in El Terreno, Palma's swanky residential section where you get the morning sun, the afternoon cocktail, and the evening boredom» (1933: 42). This suburb of Palma was one of the first organized swimming resorts in the city's bay. On its shores locals first encountered the foreigners' cult of the sun and their "vacationing» swim-suits. Waxman echoed the anxiety of the neighbors towards that «strange horde of savages that, naked of apparel and dignity, [...] invades the streets and roads of our towns and villages» (46). The journalist reported the angst of the island's most conservative sector: «Majorca is not a theatre in which to stage their

13 See Walton's «Paradise Lost and Found» (2005) to learn about the development of tourism in El Terreno neighborhood during the first half of the twentieth century. 
clownish festival» (46). American novelist Theodore Pratt also recalls these tensions between the locals and the first flux of foreign investment: «For the first six months the Majorcans were bewildered by the mad rush of these enterprises» (1933: 352). Pratt, with a fondness for controversy ${ }^{14}$, also comments that locals believed the few Americans on the island "to be crazy, and the women of these Americans, by their strange actions, such as going to cafes without escort and wearing pyjamas on the street, prostitutes» (352).

The abovementioned artist Francis Caron depicted his particular pleasure-seeking milieu. In his travelogue, the young artist described the untroubled life of the artistic and traveling community in the 1930s on the island. Caron sketched on canvas by day and made love to his models by night. His characters are a myriad of happy-go-lucky ordinary characters. Amongst many, the reader comes across Jeanne from California: «She is twenty-five, tall, exuberant, with a pink and white complexion, a nice large bosom, and pink varnished finger nails. She is often drunk, but she is a good-natured, lazy animal» (Caron 1939: 29). After a visit, «one hot, stifling afternoon» (89), she goes into Caron's studio and takes off her clothes. The artist adds: «she was muzzy with wine, and she liked to be stretched out like that and have a man looking at her» (29). Jeanne embodied the new traveler of the era on the island: lighthearted, sensual and ready for the action that they had been deprived of in their established and -purportedly- boring homes. Of course, the reader does not know whether this encounter really happened, but the construction and depiction of such scenes and scenarios has a lot to say for the island's spell in the years to come.

The image of Mallorca - as that of the Balearics- as a place to celebrate life did, however, soon disappear, or rather, was deferred. The constant social unrest during the 1930s, General Franco's coup d'état and the resulting Civil War put an end to years of Balearic enticement. Elliot Paul, American co-editor of the journal of literary experimentation transition (1927-1938) ${ }^{15}$ expressed this sudden chasm in his travel book The Life and Death of a Spanish Town (1936) ${ }^{16}$. Gertrude Stein had recommended that Paul spend some time on the Balearic Islands in the 1930s, before the outbreak of the Civil War. He did so and in his travelogue he divides his narrative into two parts: the first evokes the history of the island of Ibiza from 4000 B.C to 1936. The second part recalls the Civil War and the sudden disappearance of the island's town, its people, and their old way of life as he had known it: «the Italian and rebel troops [...] herded four hundred republicans, among whom must have been the majority of characters of this book and killed them with their machine guns» (1936: 426). The Spanish Civil War brought an end to the image of Spain as a place of joyful farmers, noble grandees, loud American tourists and indolent

14 Pratt was expelled from Spain after publishing his article «Paradise Enjoys a Boom» (1933) in which he expressed his contempt for Spaniards and their attitudes to Americans.

${ }_{15}$ The journal transition, founded in Paris by poets Eugene Jolas and Maria MacDonald, was distributed by the Shakespeare and Company bookstore, run by Sylvia Beach.

16 To know more about this book see Moyà (2007). 
sunbathers. Dark times fell upon Spain and eventually the whole continent with the coming of World War II. Mallorca would have to await the arrival of new visitors.

\section{AFTER THE WAR, THE SUN}

After the World War II, the world needed a retreat where it could fulfill its fantasies and where soldiers could lick their wounds. In the minds of many who had fought the war, the idea of the Mediterranean in general, and Mallorca in particular, lingered as a place to recover and regain a taste for life. Four years after the Axis surrender, The New York Times broadcast that «The Balearic Islands, that counted among the most popular Mediterranean vacation spots before the war, are getting ready for what is expected to be their first major post-war tourist year» (Sengstacken 1949: 19). On Mallorca, there was a conscious effort to further exploit the island's successful pre-war images ${ }^{17}$ : tranquility, sun, and sea had worked as the bread and butter of pre-war tourism so it made sense to deploy their spell further.

Mallorca's allure was further enhanced by the presence of Hollywood stars such as Grace Kelly, Ava Gardner (invited by Graves), Errol Flynn and Patricia Wymore, who enjoyed short island stays, socializing and living the good life of patio lounging and cocktail drinking. Flynn and Wymore arrived on a black 30-metre mast sailboat named Zaca; the American actress recalled: «In those years, the 1950s, we frequented Plaza Gomila [El Terreno] at night: Tito's, El Patio, Joe's. And we also sailed to wonderful beaches, only accessible by sea» (Majorca Daily Bulletin 2013). The association of Mallorca with escapade, adventure, fantasy, joy and love ${ }^{18}$ gathered momentum as never before in the twentieth century ${ }^{19}$.

It became the norm for Mallorca to be the focus of quests by adventurers, dreamers, and pleasure-seekers in the travel scene of the second half of the century. In Majorca, Paradise Not Lost: Living the Dream on a Spanish Island (2005), Chuck Maisiel recounts his voyage to the island in the 1950s with aspiring artist Caroll Graham. They chose Mallorca to make their dreams come true: "Ask yourself, haven't you had at least an island fantasy? If not, it's time you did!» (xiii). Their «island fantasy» had found in Mallorca all the elements for artistic and sensual adventure. This island-genetic code imbibed from the very sources established by Stein more than half a century before: the idea of an inspiring island-scenery that acts as a catalyst for artistic creation. Appropriately, Chapter 7 of Maisiel's narrative

${ }^{17}$ In 1951 the first gathering of the Asamblea Turística de Mallorca [Mallorca's League for Tourism] was held. Two years later, experts in tourism discussed the future of the tourist-market at the SKAL Club International Conference.

${ }_{18}$ National campaigns promoted Mallorca as a honeymoon destination. In 194661.000 people (half of the total amount of visitors) came to Majorca on a honeymoon (Seguí Llinas 2006: 8). See also Barceló i Pons (2000).

19 See Graves's Majorca Observed (1965) which dedicates various chapters to the portrayal of the island's transformation, from idyllic retreat, to garish touristic phenomenon. 
is called «And So to Work, to Write, to Paint, to Learn» (2005: 67). After discovering their personal dreamland on the island, it was time for the travelers to break the enchantment and create, be this poetry, painting or by simply documenting one's own self-discovery. Maisiel, fulfilled as a traveler, felt entitled to pass on his learnings about the island to the next generation of traveler/readers: "Whether early, late, or just when the time is right, go for the bliss, the adventure of your life» (167). Adventure and passion -again- is precisely what Robert F. Burgess recounts in To Majorca with Love (2014). The author and his partner recall scooting across Europe on a Lambretta in the 1960s. When the travelers arrived in Mallorca they agreed that the island was the perfect place to fulfill their dream: «It had been love at first sight, our winter on Majorca. It had become everything we dreamed of -an enchanted semi-tropical island in the Mediterranean halfway to Africa» (395). As a result of the quest of these dreamers and pleasure-seekers, words like "adventure», «bliss», «dream», "paradise» became the convention in the travel idiom of the time when referring to Mallorca.

Once more, the nothing-to-do-ness of American travelers with an artistic flare and a love of escapade pervades the imagery of the island. American novelist Luke Rhinehart (born George Cockcroft) also portrays, after his experience in Mallorca in the 70s, the life of artistic mavericks and hippie wannabes in the town of Deià (which he calls 'Maya'). His novel Naked Before the World: A Lovely Pornographic Love Story (2008) depicts the island town populated by «a few empty phonies [...] and a few wrecks» who would come "to write poetry» (37):

"What's Maya like?» Diane asked abruptly of Franz. «The freak center of the world», he replied cheerfully, tossing his long hair away from his left eye. «Then how did you end up here?» Diane asked ironically. «I got tired of freak centers like the Village, London, and Amsterdam and I decided I wanted to escape to a private place and be creative» (39).

Maya (or Deià) appears as a more intimate alternative «center» where "real» artists and poets dwell. Rhinehart, however (as opposed to Maisiel) was very much aware of the town's curse. The hitherto bohemian and creative sanctuary had turned into a tourist resort. The former "authentic» modus operandi turns out to be a mere emulation of the bard (that is, Graves) in a scenario where the new protagonists come to see and be seen. The advice of the old dwellers to the new visitors aspiring to write is clear: «Some people disintegrate in Maya, I don't know why, [...] but if you just avoid the hippies, my dear, you will be overwhelmed by art and creativity" (Rhinehart 2008: 45). During this period, Deià was graced with the presence of American artists such as Mary Tatum, William Waldren and of writers such as Chester Himes, Paul Spike, Nick Arnold and James Mackinley.

Two decades later, American travel writer Paul Theroux was very conscious of the island's commodification, based on the enchantment of the island-holiday product. In his Mediterranean travelogue The Pillars of Hercules (1995), Theroux states that «Majorca, sometimes called the heart of the Mediterranean for embodying all its virtues, is known in Britain as a package holiday destination, and so is a 
synonym for cheapness» (52). If Mallorca once functioned as an exotic destination for artists and was later only affordable for well-to-do American families on luxurious cruise-liners, today the island appears as «one of those place-names which [...] carries with it so many dubious associations that it has been given the status of a household word» (52). Only on his visit to Deià (already a tourist marker for the tourist with cultural leaning) does Theroux mention, with surprise, the quietness of the town (56). The travel writer briefly alludes to Graves and to what he and Riding sought, i.e. a tranquil and inexpensive life. Theroux's conclusion on his visit, however, had little to do with previous travel accounts about the island and their quest for creative inspiration. Instead, the travel author digresses about Spanish porn and the national spirit: «Spanish pornography baffled me. It seemed beyond sex, most of it. It involved children and dogs and torture; men torturing women, women being beastly to men [...]» (64). Commodified pleasure on Mallorca and its presence as an essential part of the island's reality make the travel writer feel justified in presenting a destination where not only is everything possible, but it is also permitted.

The consecration and fulfilment of one's sensual dreams is the ultimate goal of the adolescent Franny, one of the protagonists of Straub's bestseller The Vacationers: A Novel (2014). Mallorca is the perfect stage for it: «The idea of Mallorca was appealing, which promised little waves and nice breezes» (2). It seemingly is a promising scenario for enjoying a family vacation. However, the holiday turns into a Mediterranean sexual initiation for the American teenager. Franny meets Joan [Catalan for John], a handsome local tennis instructor, and is seduced by him. After chapters of sexual innuendo, Franny and the local instructor end up, in the last pages of the novel, making love under the sun in a deserted cove. The young American, blessed by the sun and the learnings and yearnings of the flesh, has her epiphany in the warm security of cliché: «[...] and now she was naked on a beach in Mallorca and maybe there was a God after all» (261). The paradise lost of a teenager normally under the restraints of family and home is now a paradise regained on the island devoted to fantasy fulfilment. The fictional character, like many others before her, has accomplished her Mediterranean island-dream.

\section{CONCLUSION}

The idea of Mallorca as Paradise has haunted the island for more than a century. Travelers have called Mallorca the "Paradise for Painters» (Harden 1924: 440) and the "Garden of Hesperides» (Duryea 1927: xv); it has been "Arcadia» (Metcalf 1933: 119) and «Paradise» (Waxman 1933: 78) for some, and "a fairy place pregnant with adventure» (Duryea 1927: vi) for others. «How could they argue with paradise?» reasons a fictional character in a popular novel who indulges herself in the pleasure of rule-breaking on Mallorca (Straub 2014: 200). Travel writers, like many others, have thought that in Mallorca they found their «island in the sun» (Burgess 2012: 211). Celebrities, like film-star Sharon Stone, help construct this narrative by appearing in the media describing their stay on Mallorca as a "weekend in paradise» (Diario de Mallorca 2018). 
For the American eye in the twentieth century, Mallorca represented a faraway ideal onto which travelers could project their desires, caprices, and creativeness. However, what started as an inexpensive destination for artists at the beginning of the twentieth century later developed into a playground for celebrities, socialites and tourists. The Hanks and the Springsteens, as well as the Steins and the Therouxs before them, came to Mallorca to savor life, but also to find inspiration and gratification in the muses and the sea. The tourism market has done the rest. Artistic life, literature, travel writing, tourist images, and popular literature have helped to construct this magic discourse and to sell it: Mallorca, the Disneyland of the senses.

Recibido: junio de 2018; ACEPTAdo: octubre de 2018. 


\section{BIBLIOGRAPHY}

Barceló i Pons, Bartomeu (2000): «Història del turisme a Mallorca», in Treballs de la Societat Catalana de Geografia 50 (xv): 31-55.

Beller, Manfred and Joep Leerssen (eds.) (2007): Imagology: The Cultural Construction and Literary Representation of National Character, Amsterdam: Rodopi.

Boyd, Mary Stuart (1911): The Fortunate Isles: Life and Travel in Majorca, Minorca and Iviza, London: Methuen.

Burgess, Robert (2014): To Majorca with Love, Chattahoochee, Florida: Spyglass Publications.

Buswell, R. J. (2011): Mallorca and Tourism: History, Economy and Environment, Bristol: Channel View Publications.

Chamberlin, Frederick (1927): The Balearics and their People, London: John Lane.

Cirer-Costa, Joan Carles (2014): «Majorca's Tourism Cluster: The Creation of an Industrial District, 1919-36», Business History 56 (8): 1243-1261.

Creeley, Robert (2002): Written in Mallorca: Poems and Stories, Palma: Aquiles Edicions.

DIARIO DE MALLORCA (2018): «Sharon Stone presume de Mallorca en el mundo y dice que la isla es un 'paraíso'” URL: https://www.diariodemallorca.es/sociedad/2018/10/03/sharon-stonepresume-mallorca-mundo/1352895.html; 03/10/2018.

Duryea, Nina Larrey (1927): Mallorca the Magnificent, New York: The Century Company.

FÁbregas, Luis (1957): Estampas del Terreno, Palma: Edicions Palma.

FLITCh, J.E. Crawford (1911): Mediterranean Moods: Footnotes of Travel in the Islands of Mallorca, Menorca, Ibiza and Sardinia, London: Grant Richards.

Fussell, Paul (1980): Abroad: British Literary Travelling Between the Wars, Oxford: Oxford University Press.

Graves, Robert (1957) [1929]: Goodbye to All That, London: Penguin.

Graves, Robert (1965): Majorca Observed, London: Cassell.

Harnden, Phoebe Binney (1924): «Keeping House in Majorca», National Geographic Magazine 45 (5): 425-440.

Harrison, Ada May (1927): A Majorca Holiday, London: Gerald Howe.

Hynes, Samuel (1976): The Auden Generation: Literature and Politics in England in the 1930s, London: Bodley Head.

Jenkins, Herbert F. (1925): «Old Majorca Has Many Charms», The New York Times (Magazine): 16.

Jessop, A. (2016): «Geopoetics and Historical Modernism: Gertrude Stein, Laura Riding, and Robert Graves in Mallorca, 1912-1936», in Adam J. Goldwyn and Renée M. Silverman (eds.), Mediterranean Modernism, New York: Palgrave Macmillan. 123-148.

Laughlin, James (1934): «A Natural History», Caravel 2 (Palma de Mallorca): 37-52.

Linares, Juan (1928): «Algo sobre turismo», in J. Martí Rosselló, Pitos y Flautas. Sports, toros, pasatiempos, teatros, noticias varias, etc., Palma: Imprenta Independencia, 34.

Lonely Planet (2017): «Mallorca is a Classic Mediterranean Postcard». URL: https://www.lonelyplanet.com/spain/mallorca/; 30/10/2017.

MacCannell, Dean (1976): The Tourist: A New Theory of the Leisure Class, New York: Schocken. 
Maisiel, Chuck (2005): Majorca, Paradise Not Lost. Living the Dream on a Spanish Island, New York: iUniverse Inc.

MAJORCA DAILY BULLETIN (2013): «Majorca Memories with Flynn». URL: https://majorcadailybulletin.com/news/local/2013/09/22/10124/majorca-memories-with-flynn.html; 23/04/2018

Metcalf, Jesse (1927): Wandering Among Forgotten Islands, New York: J.H. Seurs \& Co.

MoyÀ, Eduard (2007): «Elliot Paul and The Life and Death of a Spanish Town. Travelling and Denouncement in the Spanish Civil War», in María Antonia López Burgos and José Ruiz Mas (eds.), Travels, Travellers and Travelogues, Granada: Editorial Universidad de Granada, 55-74.

Moyà, Eduard (2015): «Palma: The Oscillating Core of a Suspended Periphery. An Imagologic Approach to an Island City and its Discourse of Pleasure», Journal of Marine and Island Studies 4: 1-9.

Moỳ̀, Eduard (2016): Journeys in the Sun: Travel Literature and Desire in the Balearic Islands (19031939), Palma: Edicions UIB.

NEW YORK TIMES (1933): «Majorca, Mediterranean Isle, Has Many American Residents», 16 July: 3.

Paul, Elliot (1936): The Life and Death of a Spanish Town, New York: Random House.

Pratt, Theodore (1933): «Paradise Enjoys a Boom», The American Mercury 28 (July): 352-356.

RhineHart, Luke (2008): Naked Before the World, Bloomington, Indiana: AuthorHouse.

Riding JaCKson, Laura (1935): «Laura Riding», Focus 1 (January): 10. URL: https://www4.ntu. ac.uk/laura_riding/archive/en-us-102782gp.html; 23/03/2018.

Rusiñol, Santiago (1981) [1922]: La isla de la calma, Barcelona: Juventud.

Rusiñol, Santiago (1936) The Tranquil Isle. Trans. Mary Lake, Palma de Mallorca: Editorial Baleares.

Seguí Llinás, Miquel (2006): El Turisme a Balears (1950-2005), Palma: Documenta Balear.

Sengstaken, Royal (1949): «Tourists Are Rediscovering Majorca», The New York Times, May 22: 19.

Stein, Gertrude (1922): Geography and Plays, Boston: The Four Seas Company Publishers.

Stein, Gertrude (1933): The Autobiography of Alice B. Toklas, New York: Harcourt, Brace and Company.

Straub, Emma (2005): «Why Should You Visit Europe’s Favourite Getaway?», Condé Nast Traveler, https://www.cntraveler.com/stories/2015-06-23/novelist-emma-straub-mallorca-spain-europe-favorite-island-getaway; 28-04-2018.

Straub, Emma (2014): The Vacationers, New York: New York Books.

Theroux, Paul (1995): The Pillars of Hercules, London: Penguin.

Ultima Hora (2013): “The Boss' surca Mallorca», 14 August. URL: https://ultimahora.es/vips/ nos-han-visitado/2013/08/14/5407/the-boss-surca-mallorca.html; 23/01/2018.

UrrY, John (1995): Consuming Places, London and New York: Routledge.

Walton, John K. (2005): «Paradise Lost and Found: Tourists and Expatriates in El Terreno, Palma de Mallorca, from the 1920s to the 1950s", in John K. Walton (ed.), Histories of Tourism: Representation, Identity and Conflict, Clevedon: Channel View Publications, 179-194.

Waxman, Percy (1933): What Price Mallorca, New York: Farrar and Rhinehart.

West, Gordon (1929): Jogging Round Majorca, London: Alston Rivers.

Zuelow, Eric G.E. (2016): A History of Modern Tourism, London \& New York: Palgrave. 
